\title{
Metformin reverses mesenchymal phenotype of primary breast cancer cells through STAT3/NF-kB pathways
}

José Esparza-López ${ }^{1,2}$, Juan Francisco Alvarado-Muñoz ${ }^{2}$, Elizabeth Escobar-Arriaga ${ }^{3}$, Alfredo Ulloa-Aguirre ${ }^{1 *}$ and María de Jesús Ibarra-Sánchez ${ }^{1,2^{*}}$ (i)

\begin{abstract}
Background: Breast cancer currently is the most frequently diagnosed neoplasm and the leading cause of death from cancer in women worldwide, which is mainly due to metastatic disease. Increasing our understanding of the molecular mechanisms leading to metastasis might thus improve the pharmacological management of the disease. Epithelial-mesenchymal transition (EMT) is a key factor that plays a major role in tumor metastasis. Some proinflammatory cytokines, like IL-6, have been shown to stimulate phenotypes consistent with EMT in transformed epithelial cells as well as in carcinoma cell lines. Since the EMT is one of the crucial steps for metastasis, we studied the effects of metformin (MTF) on EMT.
\end{abstract}

Methods: Cytotoxic effect of MTF was evaluated in eight primary breast cancer cell cultures by crystal violet assay. EMT markers and downstream signaling molecules were measured by Western blot. The effect of MTF on cell proliferation and cell migration were analyzed by MTT and Boyden chamber assays respectively.

Results: We observed that the response of cultured breast cancer primary cells to MTF varied; mesenchymal cells were resistant to $10 \mathrm{mM} \mathrm{MTF}$ and expressed Vimentin and SNAIL, which are associated with a mesenchymal phenotype, whereas epithelial cells were sensitive to this MTF dose, and expressed E-cadherin but not mesenchymal markers. Further, exposure of mesenchymal cells to MTF down-regulated both Vimentin and SNAIL as well as cell proliferation, but not cell migration. In an in vitro IL-6-induced EMT assay, primary breast cancer cells showing an epithelial phenotype underwent EMT upon exposure to IL-6, with concomitant activation of STAT3 and NF-KB; addition of MTF to IL-6-induced EMT reversed the expression of the mesenchymal markers Vimentin and SNAIL, decreased PSTAT3 Y705 and pNF-KB S536 and increased E-cadherin. In addition, downregulation of STAT3 activation was dependent on AMPK, but not NF-KB phosphorylation. Further, MTF inhibited cell proliferation and migration stimulated by IL-6.

Conclusion: These results suggest that MTF inhibits IL-6-induced EMT, cell proliferation, and migration of primary breast cancer cells by preventing the activation of STAT3 and NF-KB. STAT3 inactivation occurs through AMPK, but not NF-KB.

Keywords: Breast Cancer, Epithelial-mesenchymal transition, Metformin, STAT3, NF-KB, AMPK

\footnotetext{
* Correspondence: aulloaa@unam.mx; maria.ibarras@incmnsz.mx;

mibarra.innsz@gmail.com

${ }^{1}$ Red de Apoyo a la Investigación (RAI), Universidad Nacional Autónoma de

México- Instituto Nacional de Ciencias Médicas y Nutrición Salvador Zubirán,

Vasco de Quiroga 15, Col. Belisario Domínguez Sección XVI, Delegación

Tlalpan, 14080 Mexico City, CP, Mexico

Full list of author information is available at the end of the article
}

(c) The Author(s). 2019 Open Access This article is distributed under the terms of the Creative Commons Attribution 4.0 International License (http://creativecommons.org/licenses/by/4.0/), which permits unrestricted use, distribution, and reproduction in any medium, provided you give appropriate credit to the original author(s) and the source, provide a link to the Creative Commons license, and indicate if changes were made. The Creative Commons Public Domain Dedication waiver (http://creativecommons.org/publicdomain/zero/1.0/) applies to the data made available in this article, unless otherwise stated. 


\section{Background}

Breast cancer is a major health problem in women worldwide, with an estimated 1.7 million women diagnosed with this neoplasia in 2012 [1]. Approximately $30 \%$ of breast cancer patients will eventually develop metastatic disease, which is the main cause of death, particularly when present at distant organs. Currently, predicting accurately the risk for metastasis in a particular patient is not yet feasible. In fact, more than $80 \%$ of breast cancer patients receive adjuvant chemotherapy and approximately $40 \%$ will relapse and eventually die from metastatic disease. According to the widely held model of metastasis, rare subpopulations of cells within the primary tumor acquire advantageous genetic alterations over time, thereby enabling these cells to metastasize and form new solid tumors at distant sites [2]. Thus, increasing our understanding on the molecular mechanisms leading to metastasis might improve the clinical and pharmacological management of the disease.

The epithelial-mesenchymal transition (EMT) plays a major role in tumor progression by assisting invasion and intravasation of neoplastic cells into the bloodstream and inducing proteases involved in the degradation of the extracellular matrix (ECM) [3]. During the EMT, cell-cell junctions and cell adhesion to ECM are lost and, concomitantly, the apical-basolateral polarity is disrupted, enabling the cells to evolve into a mesenchymal phenotype with invasive properties [4]. Down-regulation of E-cadherin has been reported to reflect progression and metastasis in breast cancer associated with poor prognosis $[5,6]$. In addition, both downregulation of E-cadherin and up-regulation of Vimentin and $\mathrm{N}$-cadherin are frequently observed in cancer cells from epithelial cancers during stromal invasion [7]. Down-regulation of E-cadherin is believed to result in loss of adhesion between epithelial breast cancer cells and other epithelial cells, whereas $\mathrm{N}$-cadherin increase promotes adhesion and intrusion of tumor cells into the stroma [8]. Studying EMT in vitro has facilitated the characterization of the several signaling pathways typically involving a series of genes proposed as "EMT master genes". These genes are a group of transcription factors that include SNAIL, TWIST, ZEB and E47 [9]. Extrinsic signals from soluble mediators from the tumor microenvironment have been implicated in the regulation of EMT.

Some cytokines have been shown to stimulate phenotypes consistent with EMT in transformed epithelial as well as carcinoma cell lines. One of these is IL-6, a pleiotropic cytokine that participates in acute inflammation, and that also plays a central role in hematopoiesis, tumor progression, and proliferation; in addition, this cytokine has been found within the tumor microenvironment [10-12]. IL-6 signaling uses a specific IL-6 receptor (IL-6R/CD126) as well as a common transmembrane signal transducer, gp130 (CD130) to initiate the JAK/STAT3 and NF- $\mathrm{KB}$ signaling pathways. In fact, elevated serum levels of IL- 6 have been associated with poor prognosis of lung and breast cancer [13-15]. Several studies have found that IL-6 contributes to the induction of EMT in several types of tumors including lung, head and neck, breast, and ovarian cancers [16-19].

Since the EMT is one of the crucial steps for metastasis, there is an enormous interest to find strategies aimed to interrupt this process and to establish new strategies for cancer treatment. Metformin (MTF), an anti-diabetic drug widely prescribed for treating type 2diabetes, has been associated with reduction in the risk to develop distinct types of cancer [20-22]. Several signaling pathways have been reported as putative mechanisms involved in the anti-tumor function of MTF, including inhibition of pro-inflammatory cytokines similar to IL-6 [23] and down-regulation of EMT markers such as E-cadherin, TWIST, ZEB, and Slug [24]. In lung adenocarcinoma cells, MTF has been shown to affect IL6-induced EMT, most likely through inhibition of STAT3 phosphorylation [25]. Some anticancer effects of MTF have been associated with activation of adenosine monophosphate protein kinase (AMPK). AMPK is an energy sensor that is activated under low glucose levels, hypoxia and stress [26]. To overcome a stress condition, AMPK limits anabolic processes and activates catabolic processes to generate energy, thereby increasing cell survival under stress [27]. Another mechanism of action proposed for the MTF effects on tumor cells is through inhibition of the electron transport chain of the mitochondria, hence decreasing Complex I activity of the respiratory chain and the oxidative phosphorylation of cells [28, 29]. Moreover, inhibition of Complex I lowers the ATP production, leading to increase ADP levels that later are converted to AMP, ultimately activating AMPK [30, 31].

In the present study, we used a model of cultured primary breast cancer cells to analyze the impact of MTF on the EMT. We employed patient-derived breast cancer cell models because they represent better the molecular characteristics from the original tumors and these models are clinically relevant. We used 2 groups of primary breast cancer cells, a group with mesenchymal phenotype and another with epithelial phenotype. We found that the response to MTF is different between mesenchymal and epithelial primary breast cancer cells. MTF can suppressed basal mesenchymal markers with reduction of cell proliferation, but it did not modify cell migration rate. Furthermore, in an IL-6-induced EMT model, MTF diminished IL-6-induced cell proliferation, and migration by reducing the phosphorylation of 
STAT3- and NF-кB. Moreover, inhibition of STAT3 activation by MTF appeared to be dependent on AMPK activation, but not on the reduction of $N F-k B$ phosphorylation.

\section{Methods}

\section{Antibodies and reagents}

Recombinant human IL-6 was purchased from PeproTech (Rocky Hill, NJ, USA). E-cadherin and Vimentin antibodies were obtained from GeneTex (Irvine, CA, USA). SNAIL, pNF-кB-p65 (Ser536), pAMPK (Thr172), AMPK, GAPDH were purchased from Cell Signaling Technology (Danvers, MA, USA). STAT3, pSTAT3 Y705, NF-kB-p65, and $\beta$-actin were obtained from Santa Cruz Biotechnology (Dallas, TX, USA).

\section{Cell culture}

The primary cell cultures MBCDF, MBCD3, MBCD4, MBCD17, MBCD23, MBCD25, were derived from biopsies of mastectomies performed on patients with breast cancer. The study was approved by the Ethics and Research Committee of the Instituto Nacional de Ciencias Médicas y Nutrición Salvador Zubirán (Ref. 1549, BQ0008-06 / 9-1) as described before [32, 33]. MBCDF-D5 and MBCDF-B3 are subpopulations from the primary culture MBCDF previously characterized by EsparzaLópez et. al. [33]. Cell cultures were maintained in RPMI-1640 medium supplemented with $10 \%$ fetal bovine serum (FBS), antibiotic and antimycotic (Invitrogen Corporation, Camarillo, CA) at $37^{\circ} \mathrm{C}$ in a humidified atmosphere with $5 \% \mathrm{CO}_{2}$.

\section{Cytotoxicity assay}

Primary breast cancer cells were seeded at a density of 7500 cells $/ \mathrm{cm}^{2}$ in 48 -well plates. MTF (MP Biomedicals, Burlingame, CA) was added at increasing concentrations $(0,0.5,1,5,10,25,50$ and $100 \mathrm{mM})$, in triplicate incubations, and incubated for $48 \mathrm{~h}$. Cell viability was evaluated using the crystal violet technique. Thereafter, cells were fixed with $1.1 \%$ glutaraldehyde in PBS for $20 \mathrm{~min}$, followed by staining with $0.05 \%$ crystal violet and dissolved in $10 \%$ acetic acid before measuring the absorbance at $570 \mathrm{~nm}$ using an ELISA plate reader. The results are expressed as the percentage of viability calculated from the absorbance of a given MTF concentration with respect to the untreated control.

\section{Cell stimulation}

Primary breast cancer cells (MBCDF-D5, MBCD3, MBCDF-B3, MBCD23) were treated with $10 \mathrm{mM}$ MTF to evaluate its effect on mesenchymal markers. MBCDF, MBCD17 were induced to EMT by adding IL-6 $40 \mathrm{ng} /$ $\mathrm{mL}$. Cells were collected for protein extraction at day 0 , 1 , and 2. To induce mesenchymal-epithelial transition
(MET), MBCDF and MBCD17 were treated with four different conditions: no treatment, $40 \mathrm{ng} / \mathrm{mL}$ IL-6, 10 $\mathrm{mM}$ MTF and the combination IL-6+MTF. At day 0, an initial IL-6 treatment was given for $24 \mathrm{~h}$. Then, MTF was added with an additional dose of $40 \mathrm{ng} / \mathrm{mL}$ IL-6 to sustain EMT. These conditions were maintained for further $24 \mathrm{~h}$ and cells were collected for protein extraction. For inhibition of AMPK in MBCDF and MBCD17 cells, $10 \mu \mathrm{M}$ compound $\mathrm{C}$ (Dorsomorphin) was added $2 \mathrm{~h}$ before the addition of IL-6. To activate AMPK, MBCDF and MBCD17 cells were treated with $1 \mathrm{mM}$ AICAR $2 \mathrm{~h}$ before adding IL-6.

\section{Western blot}

Stimulated cultured primary breast cancer cells were lysed in a buffer containing $50 \mathrm{mM}$ HEPES pH7.4, $1 \mathrm{mM}$ EDTA, $250 \mathrm{mM} \mathrm{NaCl}, 1 \%$ Nonidet P-40, $10 \mathrm{mM} \mathrm{NaF}$, and $1 \mathrm{X}$ protease inhibitors (Complete EDTA-free, Roche). Twenty micrograms of whole cell lysate were subjected to SDS-PAGE and transferred to an Immobilon-P PVDF membrane (Millipore Corp. Bedford, MA). The membrane was blocked for $60 \mathrm{~min}$ in $5 \%$ non-fat milk in PBSTween and then incubated with the corresponding primary antibodies overnight at $4{ }^{\circ} \mathrm{C}$ and thereafter with secondary anti-mouse-HRP or anti-rabbit-HRP antibodies (Jackson Immuno-Research, West Grove, PA, USA). Detection of the HRP signal was performed using the ECL ${ }^{\mathrm{rm}}$ Prime Western Blotting Detection Reagent (GE Healthcare, Buckinghamshire, UK). Blot images were digitized using Chemidoc (Bio-Rad, Hercules, CA, USA).

\section{Cell proliferation}

Cell proliferation of cultured primary breast cancer cells in the presence of $10 \mathrm{ng} / \mathrm{mL}$ IL- $6,10 \mathrm{mM}$ MTF or IL$6+$ MTF was assessed by seeding 2500 cells $/ \mathrm{cm}^{2}(5000$ cells/well) in 24-well plates in RPMI 1640 supplemented with $10 \%$ FBS. Cell proliferation was analyzed by the MTT assay (3-[4,5-dimethylthiazol-2-yl]-2,5-diphenyltetrazolium bromide, Sigma-Aldrich, St Louis, MO, USA) at $0,1,3$ and 5 days. MBCDF-D5, MBCD3, MBCDF-B3 and MBD23 cells were plated at the same density as above. Cell proliferation was evaluated after addition of MTF $0,5,10$ and $25 \mathrm{mM}$ on day 0 and 5 by MTT assay. Formazan salt was dissolved with acidulated isopropanol. The absorbance was read at $530 \mathrm{~nm}$ and $630 \mathrm{~nm}$ in an ELISA reader. Results are expressed as the increase in absorbance $(570-630 \mathrm{~nm}$ ) at days 1,3 and 5 over the absorbance $(570-630 \mathrm{~nm})$ on day 0 . The experiments were repeated at least three times in triplicate incubations.

\section{Migration assay}

Cell migration of MBCDF and MBCD17 cells was carried out using a Boyden chamber assay. The upper 
chamber was sown with 30,000 -cells $/ 200 \mu \mathrm{l}$ in RPMI 1640 plus $10 \%$ of FBS. The lower chamber contained the following conditions: control (no additions), $10 \mathrm{ng} / \mathrm{mL}$ IL-6, $10 \mathrm{mM}$ MTF, or $10 \mathrm{ng} / \mathrm{mL}$ IL-6 plus $10 \mathrm{mM} \mathrm{MTF}$. In the case of MBCDF-D5, MBCD3, MBCDF-B3, and MBCD23 cells were seeded at the same density as above. MTF was added in the upper and lower chamber at 0.5 , 10 , and $25 \mathrm{mM}$. In all conditions, cells were incubated for $6 \mathrm{~h}$ at $37^{\circ} \mathrm{C}$ and $5 \% \mathrm{CO}_{2}$. Non-migrating cells were removed from the upper chamber with a cotton swap. The migrating cells on the Boyden chamber were fixed with $1.1 \%$ glutaraldehyde in PBS for $20 \mathrm{~min}$ and then stained with crystal violet for $20 \mathrm{~min}$. Cells were then counted from five random fields. The number of migrating cells was obtained by dividing the mean of the 5 fields counted by $0.001 \mathrm{~cm}^{2}$ (viewing field area) and then multiplied by the insert area $\left(0.33 \mathrm{~cm}^{2}\right)$.

\section{Statistical analysis}

Data are presented as mean \pm SEM of three independent experiments. MTF dose-response curves were analyzed by Student's t-test using SPSS 22.0. ANOVA was applied to proliferation and migration assays and multiple comparisons were then performed employing the Turkey HSD post-hoc test using GraphPad PRISM v6.01. $P<$ 0.05 was considered significant.

\section{Results}

\section{Primary breast cancer cells present variable responses to} metformin

For this study, we used a model of primary breast cancer cells derived from patients with this type of cancer. The molecular subtype of MBCDF-D5, MBCD3, MBCD23, MBCDF-B3, MBCD25, MBCD17, MBCDF and MBCD4 breast cancer cells was determined according to the expression of estrogen and progesterone receptors and HER2 (epidermal growth factor receptor 2) (Additional file 1: Table S1) [33], and the response to MTF in these primary breast cancer cell cultures was evaluated after treatment with increasing doses of MTF $(0.5,1,5$, $10,25,50$, and $100 \mathrm{mM})$. We found that these cells were distributed in two groups according to their sensitivity to MTF. At low concentrations of MTF, cell viability did not show any significant difference among all breast cancer cells. The major change was observed at 5, 10, and $25 \mathrm{mM}$ of MTF, where MBCDF-D5, MBCD3, MBCD23, and MBCDF-B3 cells were less sensitive to MTF. Cell viability varied from 92 to $68 \%$ at 5 and $10 \mathrm{mM}$ MTF doses respectively, whereas at $25 \mathrm{mM}$ MTF cell viability oscillated between 79 and 57\%. MBCD25, MBCD17, MBCDF, and MBCD4 cells were more sensitive to MTF; in these cells, viability varied from 66 and $27 \%$ at the range of 5 to $25 \mathrm{mM}$ MTF (Fig. 1a). To further study the difference in the response to MTF among the primary

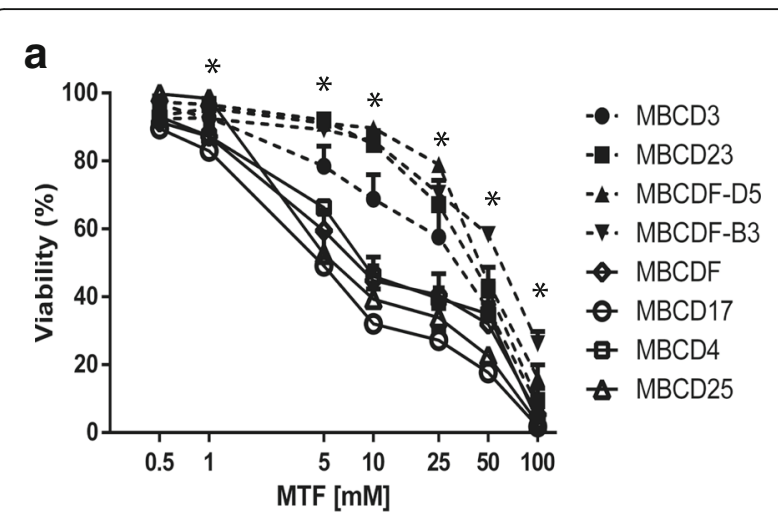

b

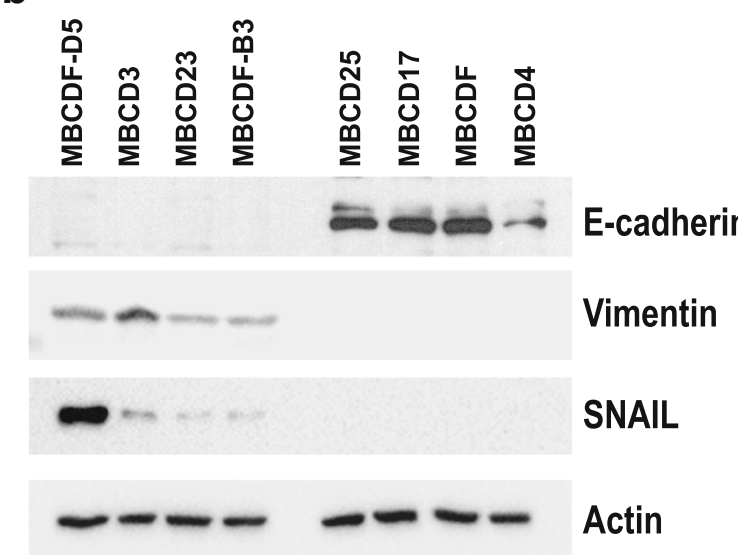

Fig. 1 Metformin-resistance correlates with mesenchymal phenotype in primary breast cancer cells. a MBCD3, MBCD23, MBCD-D5, MBCD-B3, $M B C D F, M B C D 17, M B C D 25$ primary breast cancer cell were treated with increasing concentrations of MTF and cell viability was analyzed by crystal violet after $48 \mathrm{~h}$. Data represent the mean \pm SEM of three independent experiments in triplicate incubations. ${ }^{*} P<0.001$ epithelial versus mesenchymal from 1 to $100 \mathrm{mM}$ MTF. b Representative immunoblot showing E-cadherin, Vimentin, and SNAIL EMT markers expression. Actin was used as loading control

breast cancer cells used, we calculated the half inhibitory concentration (IC50) for each primary culture. The IC50 of MBCDF-D5, MBCD3, MBCD23 and MBCDF-B3 cells varied from $23.97 \mathrm{mM}$ to $52.61 \mathrm{mM}$, while MBCD25, MBCD17, MBCDF, and MBCD4 cells exhibited IC50s from 5.31 to $11.45 \mathrm{mM}$ (Table 1).

In order to analyze for differences causing MTF resistance among these breast cancer cell lines, the status of EMT markers was measured. Interestingly, we found that MBCDF-D5, MBCD3, MBCD23, and MBCDF-B3 cells exhibited features of mesenchymal phenotype as disclosed by the lack of E-cadherin and presence of Vimentin and SNAIL, while MBCD25, MBCD17, MBCDF and MBCD4 cells expressed of E-cadherin with a concomitant absence of Vimentin and SNAIL, both distinctive of the epithelial phenotype (Fig. 1b). These data indicated that the response of primary breast cancer 
Table 1 Metformin IC50 values

\begin{tabular}{ll}
\hline Primary breast cancer cell culture & IC50 [mM] \\
\hline MBCDF-D5 & $44.70 \pm 1.06$ \\
MBCD3 & $23.97 \pm 1.97$ \\
MBCD23 & $36.55 \pm 1.07$ \\
MBCDF-B3 & $52.61 \pm 1.08$ \\
MBCD25 & $10.11 \pm 1.20$ \\
MBCD17 & $5.31 \pm 1.10$ \\
MBCDF & $11.45 \pm 1.13$ \\
MBCD4 & $8.17 \pm 1.14$ \\
\hline
\end{tabular}

cell cultures to MTF exposure varied depending on the EMT status.

\section{Metformin decreases mesenchymal markers}

Several studies have suggested that MTF reverses EMT in several types of cancer [23, 24]. With this information in mind, we examined whether MTF affected the mesenchymal markers in MBCDF-D5, MBCD3, MBCD23, and MBCDF-B3 primary breast cancer cells. Cells were treated with $10 \mathrm{mM}$ MTF for 24 and $48 \mathrm{~h}$, and expression of Vimentin and SNAIL was analyzed by Western blot. The results showed that MTF treatment reduced the amount of Vimentin and SNAIL in a timedependent manner (Fig. 2a). To examine the potential role of MTF on cell proliferation and migration of mesenchymal primary breast cancer cells, we performed cell proliferation assays in presence of MTF $0,5,10$, and 25 mM. The effect of MTF was evaluated at day 6 by MTT assay (Fig. 2b). MTF reduced proliferation in a dosedependent manner. The basal cell proliferation rate in these cells fluctuated between 7 and 12-fold. We observed that MTF $5 \mathrm{mM}$ had no significant impact on any of this type of breast cancer cells. However, MTF at 10 and $25 \mathrm{mM}$ had a major effect on cell proliferation, being MTF $25 \mathrm{mM}$ where it was more significant (Fig. 2b, Additional file 2). Next, mesenchymal breast cancer cells (MBCDF-D5, MBCD3, MBCDF-B3 and MBCD23) treated either with 10 or $25 \mathrm{mM}$ MTF for $6 \mathrm{~h}$ were used to evaluate cell migration by Boyden chamber assay (Fig. 2c). We found that cell migration was not affected by MTF at any of the two concentrations used.

\section{IL-6-induced epithelial-mesenchymal transition}

Since MTF down-regulated Vimentin and SNAIL levels in mesenchymal breast cancer primary cells, a model of EMT induction using IL-6, which is a well-known EMT inducer in several types of tumors including breast cancer [34, 35], was established. MBCDF and MBCD17 cells were treated with $40 \mathrm{ng} / \mathrm{mL}$ IL- 6 for 1 and 2 days. A slight decrease in E-cadherin expression and an increase in Vimentin and SNAIL were concomitantly observed (Fig. 3a). Further, examination of two IL-6-induced transcription factors (STAT3 and NF- $\mathrm{B}$ ) revealed that IL-6 transactivated STAT3 as shown by the presence of increased STAT3Y705 phosphorylation and a slight increase in the total amount of STAT3 in a timedependent fashion (Fig. 3b). Moreover, we found that NF- $\mathrm{kB}$ phosphorylation at S536 also was increased in response to IL-6 stimulation (Fig. 3c). These results indicate that the particular primary breast cancer cells studied can be induced to EMT by IL-6 exposure through the activation of STAT3 and NF- $\mathrm{B}$ signaling pathways.

\section{Metformin reverses IL-6-induced epithelial mesenchymal transition}

Once an IL-6-induced EMT model in primary breast cancer cells was established, we investigated whether MTF is able to reverse EMT. MBCDF and MBCD17 primary epithelial breast cancer cells were treated with 40 ng/mL IL-6; after $24 \mathrm{~h}$ of IL-6 exposure, $10 \mathrm{mM}$ MTF was added and cells were incubated for an additional 24 $\mathrm{h}$ period. As shown in Fig. 4a, IL-6 promoted EMT through lowering E-cadherin and increasing Vimentin and SNAIL. MTF alone did not exhibit a significant effect on EMT markers, while the addition of MTF to IL6 treatment provoked re-expression of E-cadherin and inhibition of IL-6-stimulated Vimentin and SNAIL expression. These results indicate that MTF reverses the EMT induced by IL-6 in primary breast cancer cells.

We next examined the effect of MTF on the activation of IL-6-induced STAT3 and NF- $\mathrm{BB}$ in MBCDF and MBCD17 primary breast cancer cells. Similar experiments to those shown in Fig. 4a were performed and activation of the STAT3 and NF- $\mathrm{BB}$ pathways was analyzed. As shown in Fig. 4b, IL-6 induced phosphorylation of Y705 on STAT3 whereas MTF alone had no effect on STAT3 activation. However, addition of MTF to IL-6 stimulation reversed the phosphorylation of STAT3 at Y705 (Fig. 4b). In addition, IL-6 provoked phosphorylation of NF-kB at S536 (Fig. 3c), and reversed this phosphorylation when MTF was combined with IL-6 (Fig. 4c). Similar results were observed in both MBCDF and MBCD17 primary breast cancer cell cultures. These data suggest that MTF reverses EMT by blocking activation of the IL-6-induced transcription factors STAT3 and $\mathrm{NF}-\mathrm{kB}$.

\section{AMPK activation is required for decrease of pSTAT3, but not pNF-kB}

Several reports have shown that MTF anticancer effects may be dependent- or independent of AMPK [36]. In order to determine the role of AMPK in MTF-reduction of STAT3 and NF- $\mathrm{kB}$ phosphorylation in MBCDF and MBCD17 cells, we used two different approaches; 

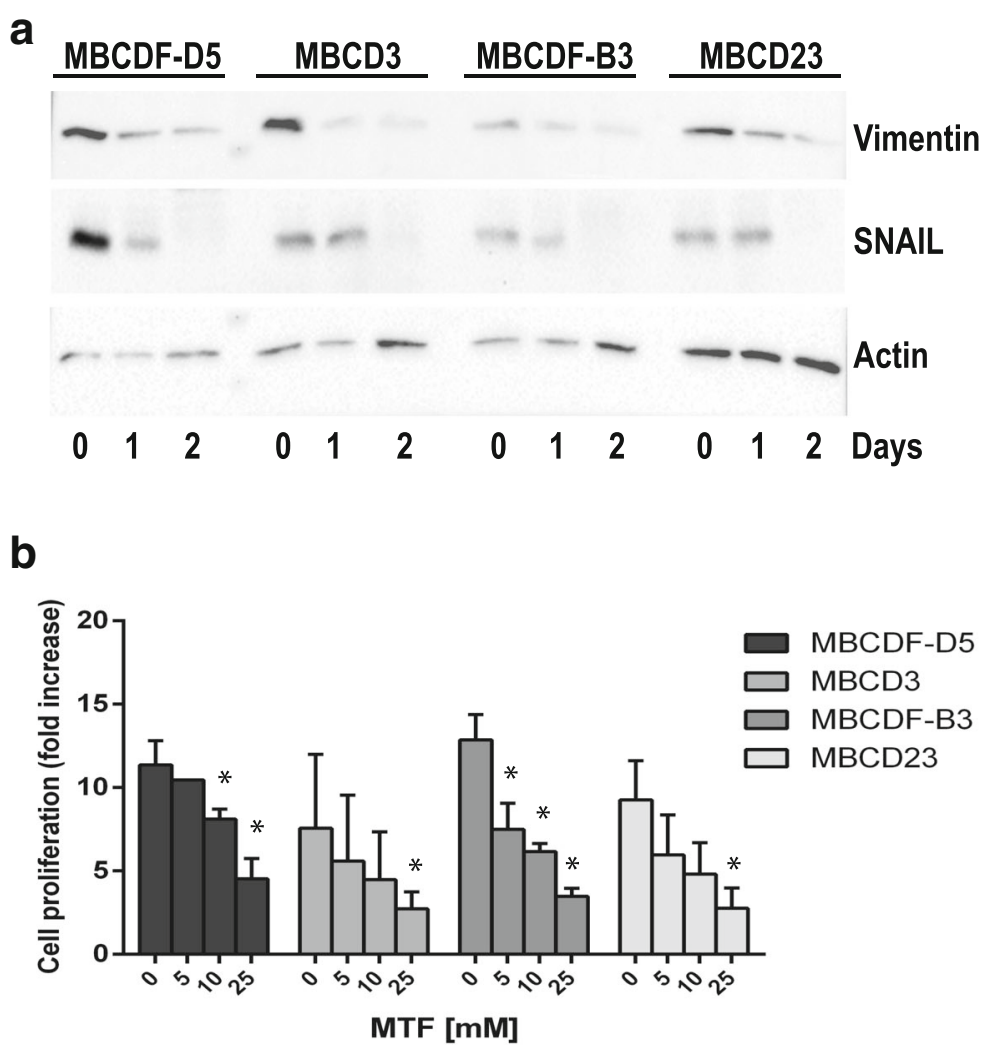

C

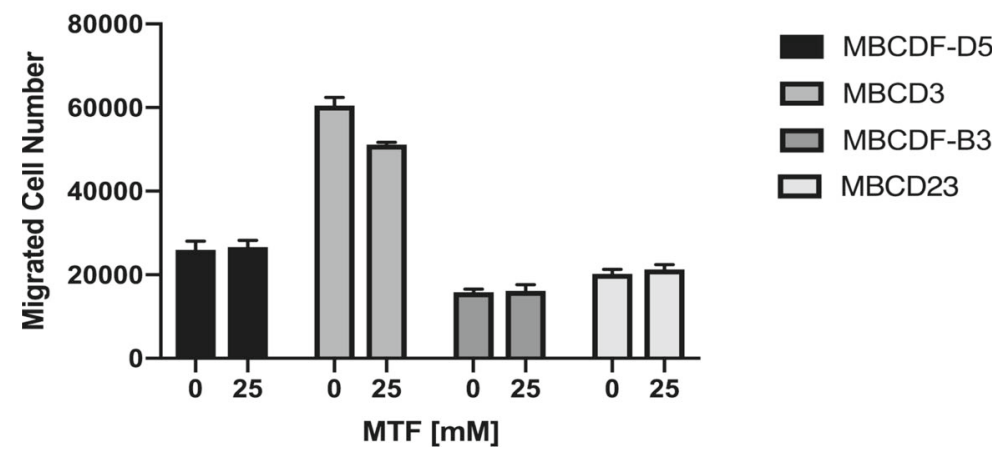

Fig. 2 Metformin reduces the expression of Vimentin and SNAIL, decreases cell proliferation but not migration in mesenchymal breast cancer cells. a Primary breast cancer cell with mesenchymal phenotype (MBCDF-D5, MBCD3, MBCDF-B3 and MBCD23) were treated with $10 \mathrm{mM} \mathrm{MTF}$ for 0, 1 and 2 days and the effect of MTF on the mesenchymal markers Vimentin and SNAIL was analyzed by immunoblotting. Actin was used as loading control. b For cell proliferation, primary breast cancer cells with mesenchymal phenotype (MBCDF-D5, MBCD3, MBCDF-B3 and MBCD23) were seeded at $2500 \mathrm{cell} / \mathrm{cm}^{2}$ (5000 cells/well) in a 24 well-plate and incubated in the absence (control) or presence of 0, 5,10, and 25 mM MTF. Cell proliferation was evaluated by MTT at days 0 , and 6 . Data represents the mean \pm SEM of three independent experiments performed in triplicate incubations. ${ }^{*} P<0.05$. c Migration assays were performed using Boyden chambers. Thirty thousand cells with mesenchymal phenotype (MBCDF$\mathrm{D} 5, \mathrm{MBCD} 3, \mathrm{MBCDF}-\mathrm{B3}$ and MBCD23) were seeded in the upper chamber in presence of MTF 0, 10 and $25 \mathrm{mM}$, the same concentrations of MTF were added in the in-bottom chamber, and then incubated for $6 \mathrm{~h}$ at $37^{\circ} \mathrm{C}$. After this time the cells that did not migrate were removed from the upper chamber. Cells that migrated were fixed and stained with Cristal Violet. Five fields were counted under the microscope at 20X. Migration assays were performed three independent times in triplicate

AMPK inhibition with compound C (Dorsomorphin), or AMPK activation using an activator, 5-aminoimidazole4-carboxamide-1- $\beta$-D-ribofuranoside (AICAR). For AMPK inhibition, $10 \mu \mathrm{M}$ compound $\mathrm{C}$ was added alone or $2 \mathrm{~h}$ before IL- 6 addition and incubated for $24 \mathrm{~h}$. After this time, compound $\mathrm{C}$ alone and compound C $+\mathrm{IL}-6$ conditions both were treated with MTF, incubation was extended further $24 \mathrm{~h}$. Activation of STAT3 and NF-kB 


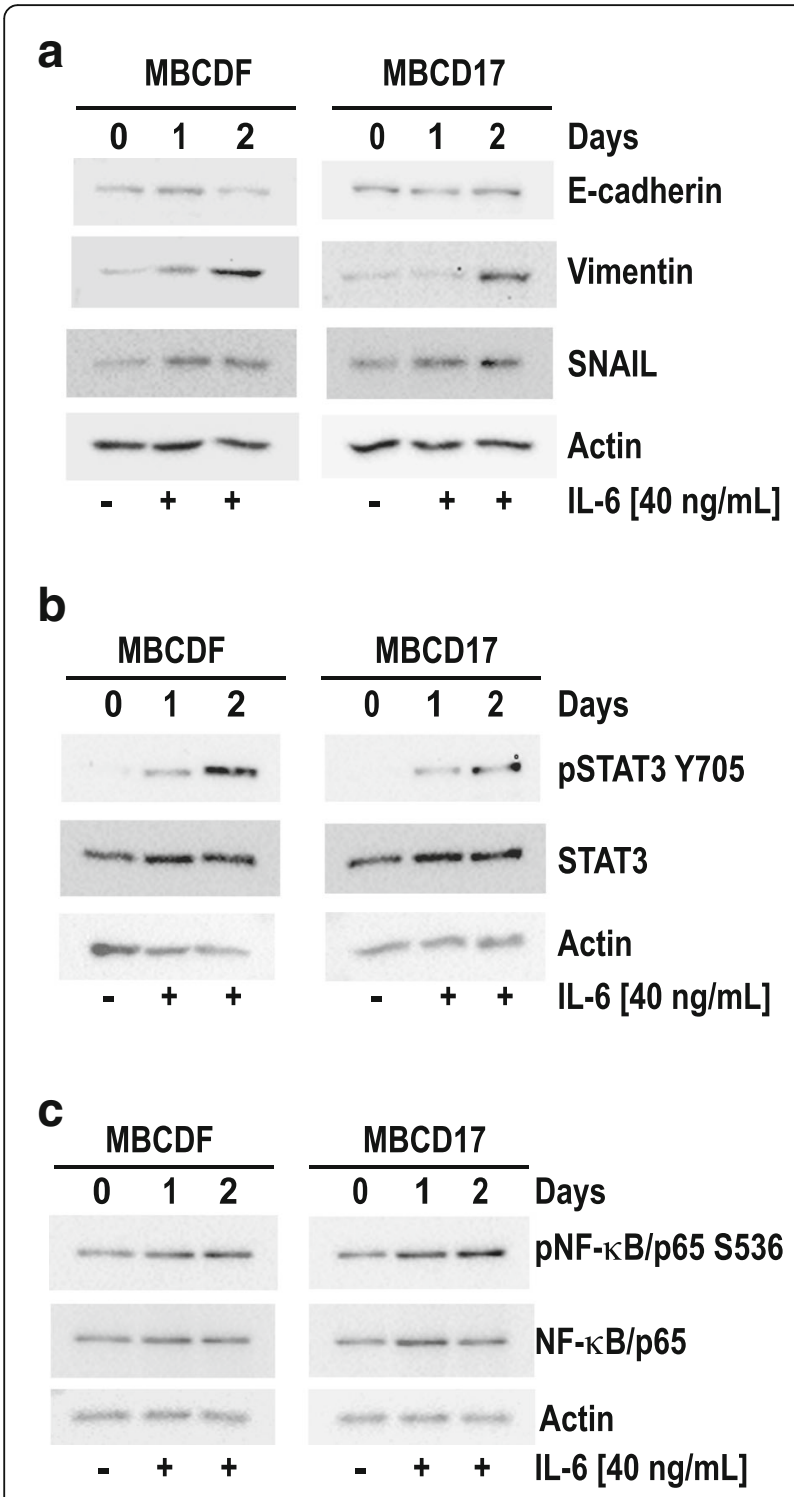

Fig. 3 Primary epithelial breast cancer cells undergo IL-6-induced EMT through STAT3 and NF-KB activation. Primary breast cancer cells with epithelial phenotype (MBCDF and MBCD17) were treated with 40 $\mathrm{ng} / \mathrm{mL}$ of IL-6 during 0, 1 and 2 days. a Induction of EMT was analyzed by assessing the expression of E-cadherin, Vimentin, and SNAIL by Western blots. $\mathbf{b}$ The activation of STAT3 was measured by phosphorylation of STAT3 on tyrosine 705 using a phospho-specific antipSTAT3 Y705 antibody. c Activation of NF-KB was assessed by analyzing phosphorylation of NF-KB/p65 on serine 536 employing a phospho-specific anti- pNF-KB S536 antibody. Actin was used as loading control in all cases

was evaluated as in Fig. 4. We observed that MTF reduced phosphorylation of both STAT3 and NF-kB as demonstrated before. Compound $\mathrm{C}$ alone did not have a significant effect on STAT3 phosphorylation (Fig. 5a, lane 5). Compound $C$ added before IL-6 increased STAT3 phosphorylation (Fig. 5a, lane 6). Combination of compound C + MTF did not affect pSTAT3 Y705 (Fig. $5 a$, line 7) and treatment with compound $\mathrm{C}+\mathrm{IL}-6+$

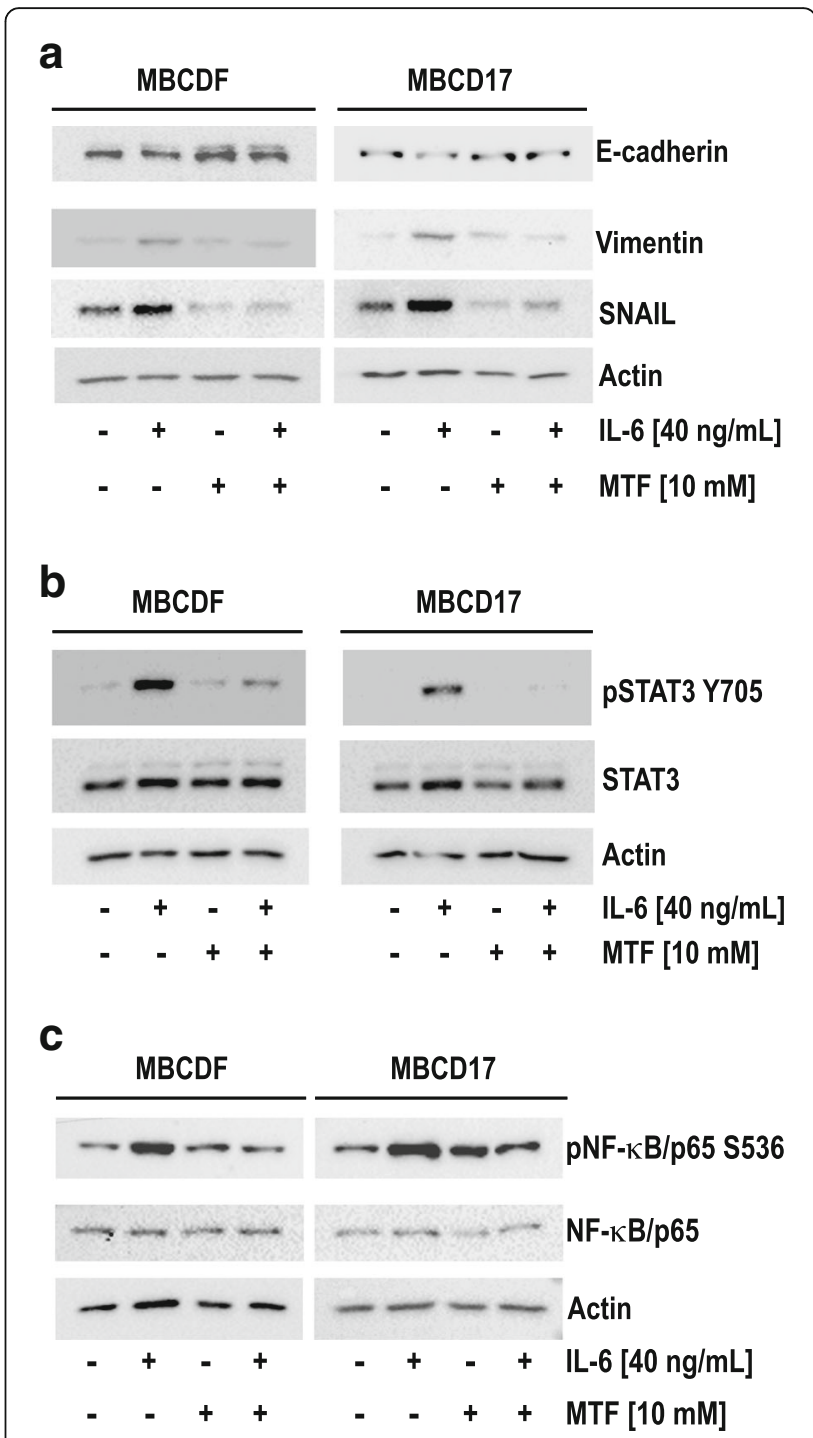

Fig. 4 Metformin reverses IL-6-induced EMT in primary epithelial breast cancer cells by inhibiting STAT3 and NF-KB phosphorylation. MBCDF and MBCD17 cells were treated with $40 \mathrm{ng} / \mathrm{mL}$ IL-6. At day 1 , MTF was added to cells incubated in the presence or absence of IL-6. After 2 days of incubation all conditions were collected for protein extraction and Western blot analysis. a Effect of MTF on IL-6-induced EMT markers (E-cadherin, Vimentin, and SNAIL). $\mathbf{b}$ Effect of MTF on IL-6-induced activation of STAT3 was assessed as in Fig. 3b. c Effect of MTF on IL-6-induced NF-KB phosphorylation was assessed as in Fig. 3c. Actin was used as loading control

MTF partially prevented the reduction of pSTAT3 Y705 (Fig. 5a, lane 8). These results suggest that AMPK inhibition with compound $\mathrm{C}$ partially interferes with the MTF-reduced STAT3 activation. In the case of NF- $k B$, we observed again that IL-6 induced NF-kB phosphorylation whereas co-treatment with MTF reduced IL-6-induced phosphorylation. Compound $\mathrm{C}$ alone exhibited opposite effects on pNF- $\kappa$ B S536, in MBCD17 increased phosphorylation while in MBCDF had no effect (Fig. 5a, 

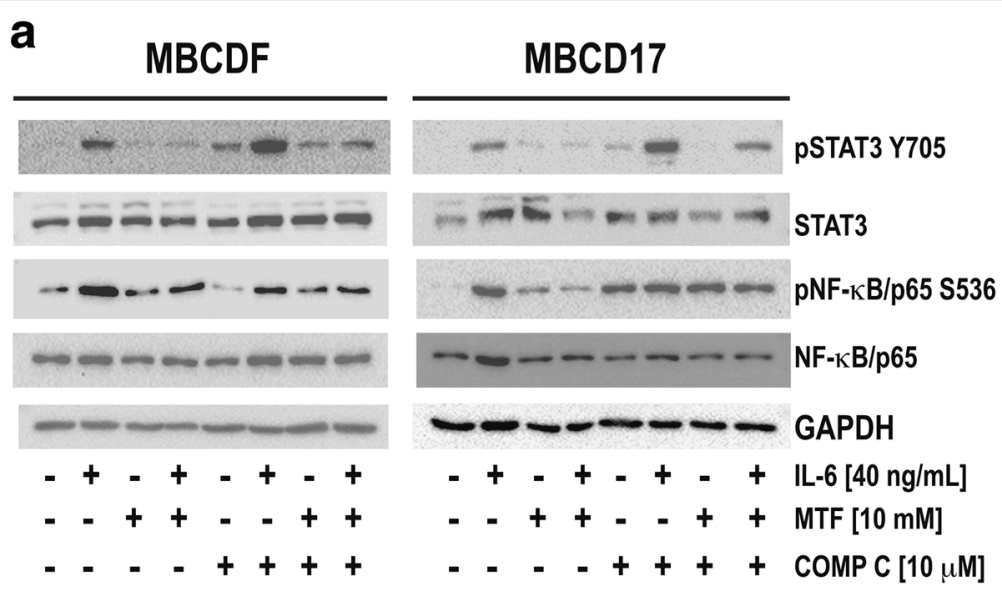

b
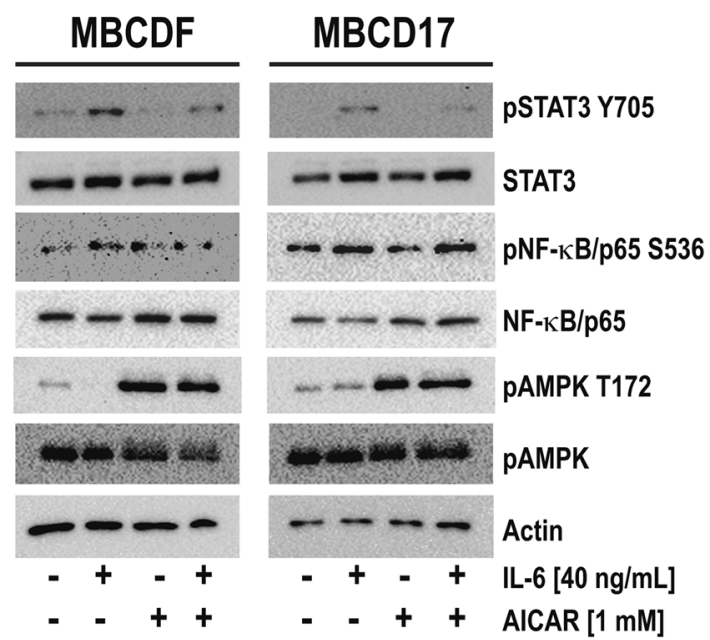

Fig. 5 Metformin effects on primary epithelial breast cancer cells are dependent of AMPK activation. a MBCDF and MBCD17 primary breast cancer cell lines were treated with $40 \mathrm{ng} / \mathrm{mL}$ IL-6. At day 1, MTF was added to cells incubated with or without IL-6. Same experiment was repeated in the presence of $10 \mu \mathrm{M}$ Compound C (COMP C) that was added $2 \mathrm{~h}$ before IL-6. The activation of STAT3 and NF-KB was measured by phosphospecific antibodies anti-pSTAT3 Y705 and anti-pNF-KB S536 antibody respectively. b MBCDF and MBCD17 cells were treated with $40 \mathrm{ng} / \mathrm{mL}$ IL-6, previous addition of $1 \mathrm{mM}$ 5-aminoimidazole-4-carboxamide-1- $\beta$-D-ribofuranoside (AICAR), an activator of AMPK kinase. The activation of STAT3, NF-KB was evaluated as in Fig. 5a. AMPK activation was measured by a phospho-specific anti-pAMPK-T172

lane 5). Both IL-6 + compound $\mathrm{C}$ and the combination of compound C + IL-6 + MTF presented similar levels of pNF-kBS536 similar to IL-6 treatment. These data suggest that the reduction in NF- $\mathrm{KB}$ activation induced by MTF is not dependent on AMPK.

Next, we examined whether AICAR-induced AMPK activation could mimic MTF reduction of IL-6-induced phosphorylation of STAT3 and NF-kB in MBCDF and MBCD17 breast cancer cells. Breast cancer cells treated with $1 \mathrm{mM}$ AICAR alone or added $2 \mathrm{~h}$ before IL- 6 were collected for protein extraction 2 days after treatment. We analyzed phosphorylation of STAT3 Y705 and NF-kB S536 (Fig. 5b). IL-6 induced phosphorylation of STAT3 Y705 whereas AICAR alone did not affect this phosphorylation; but when it was added before IL-6, IL-6-induced pSTAT3 Y705 was reduced (Fig. 5b). Next, we evaluated the effect of
AICAR on the IL-6-induced NF- $\mathrm{kB}$ phosphorylation. We found that AICAR did not interfere with IL-6-induced phosphorylation of NF-KB. These data suggest that activation of AMPK can mimic reduction of pSTAT3 Y705 similar to that observed with MTF + IL-6. However, IL-6induced pNF-kB S536 was not affected by AICAR (Fig. 5b). We confirm that AICAR induced AMPK activation by phosphorylation on T142 that indeed was increased by treatment (Fig. 5b). Together these results suggest that MTF-reduced phosphorylation of STAT3, but not NF-kB phosphorylation is dependent on AMPK activation.

\section{Metformin inhibits IL-6-induced cell proliferation and cell migration}

Since MTF interfered with IL-6-induced EMT of primary breast cancer cells, we then analyzed whether 
MTF had an effect on cell proliferation and migration. MBCDF and MBCD17 breast cancer cells were treated with IL- 6 and MTF alone or in combination and cell proliferation was assessed by MTT assay at $0,1,3$ and 5 days of stimulation. The basal rate of proliferation for MBCDF and MBCD17 cells reached 13- and 9-fold on day 6 respectively. IL-6 exposure increased cell proliferation up to 18-fold in MBCDF cells and 14-fold in MBCD17 cells. MBCDF and MBCD17 cells treated with MTF or with both IL-6 plus MTF showed a trend towards less proliferation than control cells, suggesting an inhibitory effect of MTF on IL-6-induced cell proliferation (Fig. 6a, Additional file 3). We next investigated the effect of MTF on IL-6-induced cell migration employing the Boyden chamber assay. The basal cell migration in the primary breast cancer cells studied showed different patterns, with MBCDF cells migrating more than MBCD17 cells. IL-6 treatment increased basal cell migration of both MBCDF and MBCD17 cells, whereas MTF-treated cells showed a downward trend migration when compared with control, unexposed cells. Migration in the presence of both IL-6 and MTF was similar to that exhibited by the control cells (Fig. 6b), suggesting that MTF interferes with the migration stimulated by IL- 6 .

\section{Discussion}

In the present study, we analyzed the effects of MTF on the mesenchymal phenotype and IL-6-induced EMT in cultured primary breast cancer cells. EMT is a key process in metastasis development and the major cause of mortality among breast cancer patients and evidence has been accumulated over the past decade suggesting a potential role of MTF in suppressing the progression of several types of cancer [37]. We here demonstrate that MTF displays different effects associated with the EMT status of cultured primary breast cancer cells. Mesenchymal cells were resistant to MTF and epithelial cells were sensitive to MTF. Further analysis showed that high MTF doses reduced expression of mesenchymal markers as well as IL-6-induced EMT by blocking STAT3 and NF- $\kappa B$ phosphorylation. Reduction of STAT3 phosphorylation, but not that of NF- $\mathrm{kB}$ is dependent on AMPK activation. Additionally, MTF inhibited cell proliferation of mesenchymal breast cancer cells, but not cell migration. Moreover, MTF overturned IL-6-stimulated cell proliferation and migration of cultured primary breast cancer cells.

A number of studies have suggested a potential role of MTF on the prevention and improvement of overall
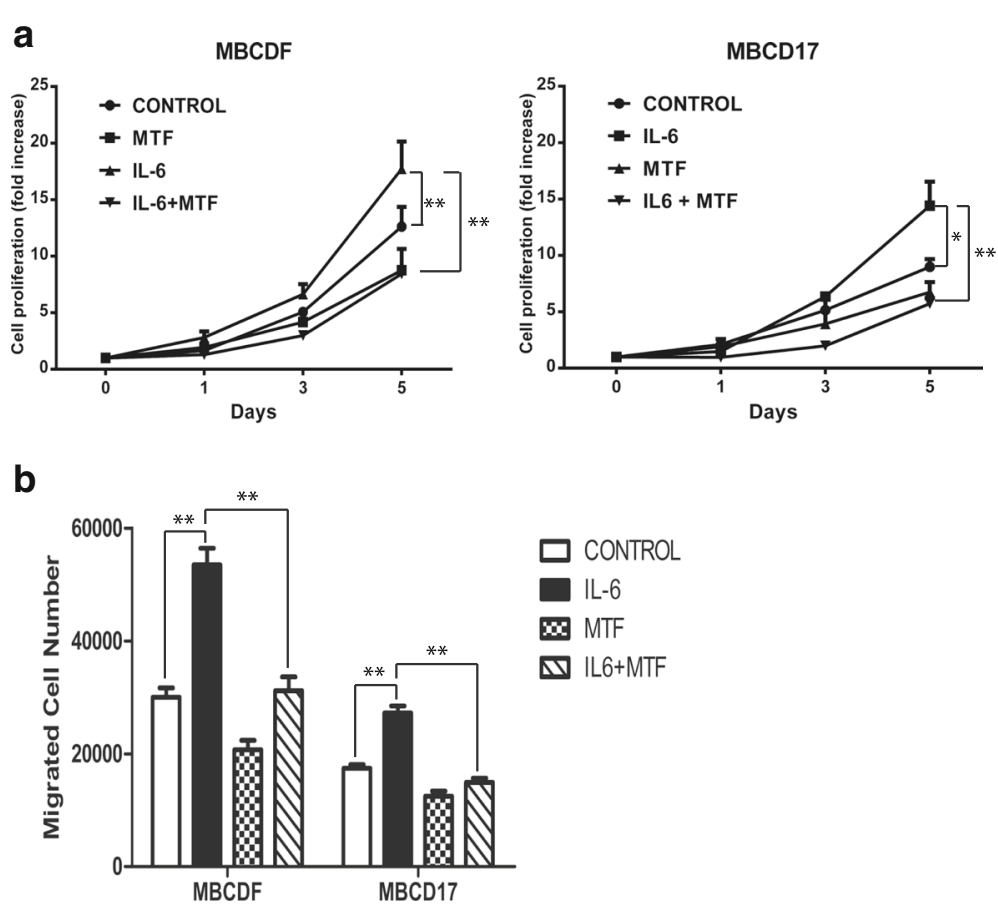

Fig. 6 Metformin inhibits IL-6-induced cell proliferation and migration. a MBCDF and MBCD17 primary breast cancer cell lines were seeded at 15000

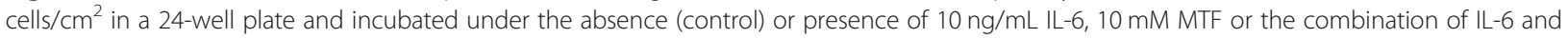
MTF. Cell proliferation was studied at days $0,1,3$, and 5 by MTT. Data represent the mean \pm SEM of three independent experiments performed in triplicate incubations. ${ }^{*} P<0.05,{ }^{*} P<0.001$. b Migration assays were tested using Boyden chambers. MBCDF and MBCD17 were seeded at 30000 cells/transwell in triplicate in the upper chamber. In the bottom chamber the same conditions were maintained as in Fig. 5a. Cells were allowed to migrate for $6 \mathrm{~h}$. Migrating cells were fixed and stained with crystal violet. Data are presented as the mean \pm SEM of three independent experiments. ${ }^{* *} P<0.001$ 
survival in breast cancer [38, 39], and proposed potential mechanisms on how MTF may affect cell survival, proliferation, migration, and inflammation [40-42]. Many of these studies have been performed using immortalized breast cancer cell lines, which have been the standard experimental paradigm employed for many years. Nevertheless, cell lines may present several drawbacks including the effects of long time in culture on the potential development of new mutations and phenotypes [43, 44]. Thus, they frequently do not fully reflect what actually occurs in in vivo conditions. In this and other studies, we have used a model of cultured primary breast cancer cells that retain most of the biochemical features of the original tumor [32,33]. Using this experimental model, we here demonstrate that the sensitivity to MTF depends on the EMT status: a mesenchymal phenotype correlated with resistance to MTF, whereas on the contrary, an epithelial phenotype was associated with sensitivity to MTF. In fact, differences in the IC50 for MTF indicated that mesenchymal cells required 4 to 10 times more MTF than epithelial cells to decrease $50 \%$ cell viability. Nonetheless, other studies have shown different effects of MTF on breast cancer cell lines. One study showed that MTF induced cell cycle arrest in estrogen receptor-positive but not in estrogen receptor-negative cells [45], while another study found that cells without expression of hormonal receptors were more responsive to this drug [46-48]. These studies proposed that differences in the response to MTF may be associated with particular breast cancer molecular subtypes [41, 47-49]. Here we demonstrate that the response to MTF in primary breast cancer cells is associated with the EMT status rather than with the molecular subtype.

During the EMT, cancer cells go through biochemical and morphological changes that allow them to acquire and enhance their invasive capacity [7]. We here show that Vimentin, SNAIL and cell proliferation decreased by MTF treatment in breast cancer cells with a mesenchymal phenotype, although these particular cells required higher doses of MTF to provoke an inhibitory effect. SNAIL expression has been associated with the repression of E-cadherin, invasion and metastases in several types of malignancies like breast, lung, hepatocellular and ovarian carcinomas [50-52]. SNAIL also has been associated as negative regulator of cell growth in lung and prostate cancer $[53,54]$. Our results of the MTF-treated mesenchymal breast cancer cell, the reduction of SNAIL expression correlates with decreasing of cell proliferation. Consequently, MTF might reduce the invasive capacity of mesenchymal primary breast cancer cells by lowering SNAIL and Vimentin, which are also important factors involved in the structural changes of the cytoskeleton and thus in cell motility and invasiveness creating a phenotypic switch [55]. In fact, several studies have found that MTF represses EMT in several tumors including cervical cancer cells [56], thyroid cancer cells [57], hepatocellular carcinoma [58] and lung adenocarcinoma [25] by reducing the levels of these factors.

It has been shown that resumption of EMT promoted by growth factors and pro-inflammatory cytokines present in the tumor microenvironment is closely linked to this epithelial cell transformation and the acquisition of a metastatic phenotype $[59,60]$. Factors involved in EMT in cancer include TNF, IL-1, and IL-4, which in turn activate several transcription factors that promote EMT [59]. Zinc finger protein SNAI1 or SNAIL is one of the transcription factors that regulate EMT and whose expression is governed by STAT3 [18]. In the present study, we tested whether primary cultures of breast cancer epithelial cells develop EMT when exposed to IL-6, a well-known pro-inflammatory cytokine that promotes EMT in several cancers via the JAK-STAT3-SNAIL signaling pathway [16-19]. We found that in cells exposed to IL-6, levels of Vimentin and SNAIL increased, albeit the changes observed in E-cadherin were subtle when compared to those previously detected in cell lines derived from lobular breast cancer tumors [61]. Nevertheless, our results correlate with previous studies in triple negative breast cancer cells, in which EMT induction was not associated to E-cadherin loss; in these particular cells, loss of E-cadherin expression was apparently an event occurring after the morphological changes promoted by EMT [61].

In addition to analyzing changes in biomarkers of EMT, we studied the activation of two transcription factors, STAT3 and NF-kB, both closely linked to EMT and activated by IL-6 $[19,62,63]$. These transcription factors, which regulate expression of Vimentin and SNAIL, increased in cultured primary breast cancer cells in response to IL-6. In this setting, we then explored the effects of MTF on IL-6-induced EMT. We found that MTF reduced IL-6-promoted upregulation of Vimentin and SNAIL allowing, in parallel, the recovering of E-cadherin levels from the subtle downregulation provoked by IL-6 exposure. Further, MTF also prevented IL-6-stimulated STAT3 and NF-kB phosphorylation. Concurrently, these data indicate that MTF inhibits EMT promoted by IL-6 by inhibiting STAT3 and NF- $\mathrm{kB}$ signaling, thereby reversing the cells to a less mesenchymal and invasive phenotype. Anticancer activities of MTF have been associated with activation of AMPK in a dependent or independent manner. AMPK is an energy sensor that is activated by several types of stress such as hypoxia, low glucose levels, oxidative stress, etc. [27]. On the other hand, AMPK has been described as a negative regulator of inflammatory response to IL-1, IL-6 and TNF [64]. We explored the putative role of AMPK in MTF-induced 
reduction of STAT3 and NF- $\mathrm{kB}$ phosphorylation. Our results show that inhibition of AMPK by using compound C blocks the inhibition of STAT3 phosphorylation provoked by MTF. We use another approach that consisted in the activation of AMPK by AICAR trying to mimic the effect of MTF; indeed, we observe that pre-treatment with AICAR before IL-6 reduces phosphorylation of STAT3. These data suggest that reduction of phosphorylation of STAT3 is mediated by AMPK. However, neither inhibition nor activation of AMPK affected MTF-mediated reduction of NF- $\mathrm{kB}$ phosphorylation.

It is also known that IL-6 participates in the regulation of migration and invasiveness of several types of cancer cells [15], including nasopharyngeal carcinoma cells, in which blocking of the IL-6 receptor by a specific monoclonal antibody reversed both processes and also EMT [65]. The effects of MTF on the proliferation and migration of cell lines derived from fibrosarcoma as well as from carcinomas of the thyroid, prostate, and pancreas also have been reported [57, 66, 67]. Considering this information, we explored the effects of this drug on the proliferation and migration of breast cancer cells with an initial epithelial phenotype and that were transformed to a mesenchymal phenotype by the exposure to IL-6. We found that MTF consistently inhibited both proliferation and migration of these cells, most probably by the reduction of IL-6-induced SNAIL and by antagonizing the effects of IL- 6 on STAT3 and NF- $\mathrm{B}$ B phosphorylation. These results are in line with data from studies in cholangiocarcinoma cells suggesting that MTF inhibits migration and invasion through inactivation of the STAT3-mediated signaling pathway [68]. Our study additionally demonstrated that NF- $\mathrm{kB}$ activation may also be affected by MTF.

\section{Conclusions}

In summary, the data presented herein indicate that the inhibitory effect of MTF on primary breast cancer cells depends on the EMT status. MTF efficiently decreases Vimentin, SNAIL and cell proliferation in mesenchymal breast cancer cells and also reverses IL-6-induced EMT by blocking STAT3 and NF-kB phosphorylation. Inhibition of STAT3 activation depends on AMPK activity. Further, MTF inhibits cell proliferation and cell migration induced by IL-6. These data suggest that MTF may represent a useful therapeutic strategy to reverse the metastatic phenotype, supporting its potential application as an add-on treatment associated to chemotherapy in breast cancer patients.

\section{Additional files}

Additional file 1: Table S1. Molecular classification of primary breast cancer cells. (PDF $21 \mathrm{~kb}$ )
Additional file 2: Effect of MTF on primary breast cancer cells with mesenchymal phenotype. Cell proliferation of primary breast cancer cells with mesenchymal phenotype (MBCDF-D5, MBCD3, MBCDF-B3 and MBCD23) was assessed in a 24 well plate, were $2500 \mathrm{cell} / \mathrm{cm}^{2}$ were seeded (5000 cells/well) and incubated under the absence (control) or presence 5,10 , and $25 \mathrm{mM}$ of MTF for 6 days. Phase-contrast images show the density of cells in a representative field of the well at day 6 . Magnification 10X. (PDF $96 \mathrm{~kb}$ )

Additional file 3: Effect of MTF on primary breast cancer cells with epithelial phenotype incubated with IL-6 and MTF. MBCDF and MBCD 17 primary breast cancer cell lines were seeded at 15000 cells $/ \mathrm{cm}^{2}$ in a 24well plate and incubated under the absence (control) or presence of IL-6 $10 \mathrm{ng} / \mathrm{mL}$, MTF $10 \mathrm{mM}$ or the combination of IL-6 and MTF. Phasecontrast images show the density of cells in a representative field of the well at days $0,1,3$, and 5. Magnification 10X. (PDF $89 \mathrm{~kb}$ )

\section{Abbreviations}

AMPK: Adenosine monophosphate protein kinase; EMT: Epithelial mesenchymal transition; ER: Estrogen receptor; HER2: Epidermal growth factor receptor 2; IL-1: Interleukin-1; IL-4: Interleukin-4; IL-6 : Interleukin-6; MTF: Metformin; NF-KB: Nuclear factor-KB; PR: Progesterone receptor; STAT3: Signal transducer and activator of transcription 3; TNF: Tumor necrosis factor

\section{Acknowledgments}

We are grateful to Dr. Alberto Huberman and Dr. Leticia Rocha-Zavaleta for their critical review of the manuscript. We are grateful to Dr. Juan Francisco Martínez-Aguilar who kindly provided the AMPK antibodies and to Dr. Gabriela Aleman Escondrillas for kindly donating AICAR and Compound C. JEL, AU-A, and MJIS belong to the Sistema Nacional de Investigadores (SNI), CONACyT, Mexico.

\section{Authors' contributions}

JEL established the primary breast cancer cells, performed all Western blots, and participated in data analyses and writing of the manuscript. JFAM performed the proliferation and migration experiments. EEA participated in data and statistical analyses. AUA participated in data analysis, manuscript review and writing of the final document. MJIS designed and coordinated the whole study, reviewed data, and wrote the manuscript. all authors have read and approved the final version of the manuscript.

\section{Funding}

This study was supported by funds from the Instituto Nacional de Ciencias Médicas y Nutrición Salvador Zubirán (INCMNSZ) to the Unidad de Bioquímica and from the Universidad Nacional Autónoma de México to the Red de Apoyo a la Investigación (RAI), Mexico City, Mexico. Sponsors did not play any role in the design, data collection, analysis, interpretation, writing and decision to publish the manuscript.

\section{Availability of data and materials}

The datasets used and/or analyzed during the current study are available from the corresponding author on reasonable request.

\section{Ethics approval and consent to participate}

To generate the primary breast cancer cell cultures a small tumor tissue was taken during surgery from a patient with breast cancer. Patients signed a written informed consent for protocol approved by the Ethics and Research Committee of the Instituto Nacional de Ciencias Médicas y Nutrición Salvador Zubirán (Ref. 1549, BQ0-008-06/9-1).

\section{Consent for publication}

Not applicable.

\section{Competing interests}

The authors declare that they have no competing interests.

\section{Author details}

${ }^{1}$ Red de Apoyo a la Investigación (RAl), Universidad Nacional Autónoma de México- Instituto Nacional de Ciencias Médicas y Nutrición Salvador Zubirán, Vasco de Quiroga 15, Col. Belisario Domínguez Sección XVI, Delegación 
Tlalpan, 14080 Mexico City, CP, Mexico. ${ }^{2}$ Unidad de Bioquímica, Instituto Nacional de Ciencias Médicas y Nutrición, Salvador Zubirán Vasco de Quiroga 15, Col. Belisario Domínguez Sección XVI, Delegación Tlalpan, 14080 Mexico City, CP, Mexico. ${ }^{3}$ Hospital Ángeles del Pedregal, Camino a Santa Teresa \# 1055, Col. Héroes de Padierna, 10700 Mexico City, CP, Mexico.

Received: 7 December 2018 Accepted: 16 July 2019

Published online: 23 July 2019

\section{References}

1. Ferlay J, Soerjomataram I, Dikshit R, Eser S, Mathers C, Rebelo M, et al. Cancer incidence and mortality worldwide: sources, methods and major patterns in GLOBOCAN 2012. Int J Cancer J Int Cancer. 2015;136(5):E359-86.

2. Celia-Terrassa T, Kang Y. Distinctive properties of metastasis-initiating cells. Genes Dev. 2016:30(8):892-908.

3. Ota I, Li XY, Hu Y, Weiss SJ. Induction of a MT1-MMP and MT2-MMPdependent basement membrane transmigration program in cancer cells by Snail1. Proc Natl Acad Sci U S A. 2009;106(48):20318-23.

4. Wendt MK, Taylor MA, Schiemann BJ, Schiemann WP. Down-regulation of epithelial cadherin is required to initiate metastatic outgrowth of breast cancer. Mol Biol Cell. 2011;22(14):2423-35.

5. Gould Rothberg BE, Bracken MB. E-cadherin immunohistochemical expression as a prognostic factor in infiltrating ductal carcinoma of the breast: a systematic review and meta-analysis. Breast Cancer Res Treat. 2006; 100(2):139-48.

6. Kowalski PJ, Rubin MA, Kleer CG. E-cadherin expression in primary carcinomas of the breast and its distant metastases. Breast Cancer Res. 2003; 5(6):R217-22.

7. Yilmaz M, Christofori G. Mechanisms of motility in metastasizing cells. Mol Cancer Res. 2010;8(5):629-42.

8. Cavallaro U, Christofori G. Cell adhesion and signalling by cadherins and IgCAMs in cancer. Nat Rev Cancer. 2004;4(2):118-32.

9. Thiery JP. Epithelial-mesenchymal transitions in tumour progression. Nat Rev Cancer. 2002;2(6):442-54.

10. Yeh HH, Lai WW, Chen HH, Liu HS, Su WC. Autocrine IL-6-induced Stat3 activation contributes to the pathogenesis of lung adenocarcinoma and malignant pleural effusion. Oncogene. 2006;25(31):4300-9.

11. Park EJ, Lee JH, Yu GY, He G, Ali SR, Holzer RG, et al. Dietary and genetic obesity promote liver inflammation and tumorigenesis by enhancing IL-6 and TNF expression. Cell. 2010;140(2):197-208.

12. Sasser AK, Mundy BL, Smith KM, Studebaker AW, Axel AE, Haidet AM, et al. Human bone marrow stromal cells enhance breast cancer cell growth rates in a cell line-dependent manner when evaluated in 3D tumor environments. Cancer Lett. 2007;254(2):255-64.

13. Koh E, lizasa T, Yamaji H, Sekine $Y$, Hiroshima K, Yoshino I, et al. Significance of the correlation between the expression of interleukin 6 and clinical features in patients with non-small cell lung cancer. Int J Surg Pathol. 2012; 20(3):233-9.

14. Kozlowski L, Zakrzewska I, Tokajuk P, Wojtukiewicz MZ. Concentration of interleukin-6 (IL-6), interleukin-8 (IL-8) and interleukin-10 (IL-10) in blood serum of breast cancer patients. Rocz Akad Med Bialymst. 2003;48:82-4.

15. Lippitz BE, Harris RA. Cytokine patterns in cancer patients: a review of the correlation between interleukin 6 and prognosis. Oncoimmunology. 2016; 5(5):e1093722.

16. Colomiere M, Ward AC, Riley C, Trenerry MK, Cameron-Smith D, Findlay J, et al. Cross talk of signals between EGFR and IL-6R through JAK2/STAT3 mediate epithelial-mesenchymal transition in ovarian carcinomas. $\mathrm{Br}$ J Cancer. 2009;100(1):134-44

17. Lee SO, Yang $X$, Duan S, Tsai $Y$, Strojny LR, Keng P, et al. IL-6 promotes growth and epithelial-mesenchymal transition of CD133+ cells of non-small cell lung cancer. Oncotarget. 2016;7(6):6626-38.

18. Sullivan NJ, Sasser AK, Axel AE, Vesuna F, Raman V, Ramirez N, et al. Interleukin-6 induces an epithelial-mesenchymal transition phenotype in human breast cancer cells. Oncogene. 2009;28(33):2940-7.

19. Yadav A, Kumar B, Datta J, Teknos TN, Kumar P. IL-6 promotes head and neck tumor metastasis by inducing epithelial-mesenchymal transition via the JAK-STAT3-SNAIL signaling pathway. Mol Cancer Res. 2011;9(12):1658-67.

20. Berstein LM, Boyarkina MP, Teslenko SY. Familial diabetes is associated with reduced risk of cancer in diabetic patients: a possible role for metformin. Med Oncol. 2012;29(2):1308-13.
21. Evans JM, Donnelly LA, Emslie-Smith AM, Alessi DR, Morris AD. Metformin and reduced risk of cancer in diabetic patients. Bmj. 2005;330(7503):1304-5.

22. Kourelis TV, Siegel RD. Metformin and cancer: new applications for an old drug. Med Oncol. 2012;29(2):1314-27.

23. Isoda K, Young JL, Zirlik A, MacFarlane LA, Tsuboi N, Gerdes N, et al. Metformin inhibits proinflammatory responses and nuclear factor-kappaB in human vascular wall cells. Arterioscler Thromb Vasc Biol. 2006;26(3):611-7.

24. Vazquez-Martin A, Oliveras-Ferraros C, Cufi S, Del Barco S, Martin-Castillo B, Menendez JA. Metformin regulates breast cancer stem cell ontogeny by transcriptional regulation of the epithelial-mesenchymal transition (EMT) status. Cell Cycle. 2010;9(18):3807-14.

25. Zhao Z, Cheng X, Wang Y, Han R, Li L, Xiang T, et al. Metformin inhibits the IL-6-induced epithelial-mesenchymal transition and lung adenocarcinoma growth and metastasis. PLoS One. 2014;9(4):e95884.

26. Kahn BB, Alquier T, Carling D, Hardie DG. AMP-activated protein kinase: ancient energy gauge provides clues to modern understanding of metabolism. Cell Metab. 2005;1(1):15-25.

27. Jeon SM, Chandel NS, Hay N. AMPK regulates NADPH homeostasis to promote tumour cell survival during energy stress. Nature. 2012;485(7400):661-5.

28. Andrzejewski S, Gravel SP, Pollak M, St-Pierre J. Metformin directly acts on mitochondria to alter cellular bioenergetics. Cancer Metab. 2014;2:12.

29. Griss T, Vincent EE, Egnatchik R, Chen J, Ma EH, Faubert B, et al. Metformin antagonizes Cancer cell proliferation by suppressing mitochondrialdependent biosynthesis. PLoS Biol. 2015;13(12):e1002309.

30. Xiao B, Sanders MJ, Underwood E, Heath R, Mayer FV, Carmena D, et al. Structure of mammalian AMPK and its regulation by ADP. Nature. 2011;472(7342):230-3.

31. Miller RA, Chu Q, Xie J, Foretz M, Viollet B, Birnbaum MJ. Biguanides suppress hepatic glucagon signalling by decreasing production of cyclic AMP. Nature. 2013;494(7436):256-60.

32. Esparza-Lopez J, Medina-Franco H, Escobar-Arriaga E, Leon-Rodriguez E, Zentella-Dehesa A, Ibarra-Sanchez MJ. Doxorubicin induces atypical NFkappaB activation through c-Abl kinase activity in breast cancer cells. J Cancer Res Clin Oncol. 2013;139(10):1625-35.

33. Esparza-Lopez J, Ramos-Elias PA, Castro-Sanchez A, Rocha-Zavaleta L, Escobar-Arriaga E, Zentella-Dehesa A, et al. Primary breast cancer cell culture yields intra-tumor heterogeneous subpopulations expressing exclusive patterns of receptor tyrosine kinases. BMC Cancer. 2016;16(1):740.

34. Miao JW, Liu LJ, Huang J. Interleukin-6-induced epithelial-mesenchymal transition through signal transducer and activator of transcription 3 in human cervical carcinoma. Int J Oncol. 2014;45(1):165-76.

35. Saglam O, Unal ZS, Subasi C, Ulukaya E, Karaoz E. IL-6 originated from breast cancer tissue-derived mesenchymal stromal cells may contribute to carcinogenesis. Tumour Biol. 2015;36(7):5667-77.

36. Ikhlas S, Ahmad M. Metformin: insights into its anticancer potential with special reference to AMPK dependent and independent pathways. Life Sci. 2017;185:53-62.

37. Pernicova I, Korbonits M. Metformin--mode of action and clinical implications for diabetes and cancer. Nat Rev Endocrinol. 2014;10(3):143-56.

38. Tsilidis KK, Capothanassi D, Allen NE, Rizos EC, Lopez DS, van Veldhoven K, et al. Metformin does not affect cancer risk: a cohort study in the U.K. clinical practice research datalink analyzed like an intention-to-treat trial. Diabetes Care. 2014;37(9):2522-32.

39. Tang GH, Satkunam M, Pond GR, Steinberg GR, Blandino G, Schunemann $\mathrm{HJ}$, et al. Association of metformin with breast cancer incidence and mortality in patients with type 2 diabetes: a GRADE assessed systematic review and meta-analysis. Cancer Epidemiol Biomark Prev. 2018.

40. Blandino G, Valerio M, Cioce M, Mori F, Casadei L, Pulito C, et al. Metformin elicits anticancer effects through the sequential modulation of DICER and cMYC. Nat Commun. 2012;3:865.

41. Amaral MEA, Nery LR, Leite CE, de Azevedo Junior WF, Campos MM. Preclinical effects of metformin and aspirin on the cell lines of different breast cancer subtypes. Investig New Drugs. 2018.

42. Hirsch HA, Iliopoulos D, Struhl K. Metformin inhibits the inflammatory response associated with cellular transformation and cancer stem cell growth. Proc Natl Acad Sci U S A. 2013;110(3):972-7.

43. Cree IA, Glaysher S, Harvey AL. Efficacy of anti-cancer agents in cell lines versus human primary tumour tissue. Curr Opin Pharmacol. 2010;10(4):375-9.

44. Gillet JP, Calcagno AM, Varma S, Marino M, Green LJ, Vora MI, et al. Redefining the relevance of established cancer cell lines to the study of mechanisms of clinical anti-cancer drug resistance. Proc Natl Acad Sci U S A. 2011;108(46):18708-13. 
45. Hadad SM, Hardie DG, Appleyard V, Thompson AM. Effects of metformin on breast cancer cell proliferation, the AMPK pathway and the cell cycle. Clin Transl Oncol. 2014;16(8):746-52.

46. Liu B, Fan Z, Edgerton SM, Deng XS, Alimova IN, Lind SE, et al. Metformin induces unique biological and molecular responses in triple negative breast cancer cells. Cell Cycle. 2009;8(13):2031-40.

47. Alimova IN, Liu B, Fan Z, Edgerton SM, Dillon T, Lind SE, et al. Metformin inhibits breast cancer cell growth, colony formation and induces cell cycle arrest in vitro. Cell Cycle. 2009;8(6):909-15.

48. Scherbakov AM, Sorokin DV, Tatarskiy W Jr, Prokhorov NS, Semina SE, Berstein LM, et al. The phenomenon of acquired resistance to metformin in breast cancer cells: the interaction of growth pathways and estrogen receptor signaling. IUBMB Life. 2016;68(4):281-92.

49. Gao ZY, Liu Z, Bi MH, Zhang JJ, Han ZQ, Han X, et al. Metformin induces apoptosis via a mitochondria-mediated pathway in human breast cancer cells in vitro. Exp Ther Med. 2016;11(5):1700-6.

50. Cano A, Perez-Moreno MA, Rodrigo I, Locascio A, Blanco MJ, del Barrio MG, et al. The transcription factor snail controls epithelial-mesenchymal transitions by repressing E-cadherin expression. Nat Cell Biol. 2000;2(2):76-83.

51. de Herreros $A G$, Peiro $S$, Nassour M, Savagner P. Snail family regulation and epithelial mesenchymal transitions in breast cancer progression. J Mammary Gland Biol Neoplasia. 2010;15(2):135-47.

52. Yang $X$, Han M, Han H, Wang B, Li S, Zhang Z, et al. Silencing snail suppresses tumor cell proliferation and invasion by reversing epithelial-tomesenchymal transition and arresting G2/M phase in non-small cell lung cancer. Int J Oncol. 2017;50(4):1251-60.

53. Come C, Magnino F, Bibeau F, De Santa Barbara P, Becker KF, Theillet C, et al. Snail and slug play distinct roles during breast carcinoma progression. Clin Cancer Res. 2006;12(18):5395-402.

54. Vega S, Morales AV, Ocana OH, Valdes F, Fabregat I, Nieto MA. Snail blocks the cell cycle and confers resistance to cell death. Genes Dev. 2004;18(10):1131-43.

55. Liu CY, Lin HH, Tang MJ, Wang YK. Vimentin contributes to epithelialmesenchymal transition cancer cell mechanics by mediating cytoskeletal organization and focal adhesion maturation. Oncotarget. 2015;6(18): 15966-83.

56. Cheng K, Hao M. Metformin inhibits TGF-beta1-induced epithelial-tomesenchymal transition via PKM2 relative-mTOR/p70s6k signaling pathway in cervical carcinoma cells. Int J Mol Sci. 2016;17(12).

57. Han B, Cui H, Kang L, Zhang X, Jin Z, Lu L, et al. Metformin inhibits thyroid cancer cell growth, migration, and EMT through the mTOR pathway. Tumour Biol. 2015;36(8):6295-304.

58. Chengye W, Yu T, Ping S, Deguang S, Keyun W, Yan W, et al. Metformin reverses bFGF-induced epithelial-mesenchymal transition in HCC cells. Oncotarget. 2017;8(61):104247-57.

59. Suarez-Carmona M, Lesage J, Cataldo D, Gilles C. EMT and inflammation: inseparable actors of cancer progression. Mol Oncol. 2017;11(7):805-23.

60. Liu CY, Xu JY, Shi XY, Huang W, Ruan TY, Xie P, et al. M2-polarized tumorassociated macrophages promoted epithelial-mesenchymal transition in pancreatic cancer cells, partially through TLR4/IL-10 signaling pathway. Lab Investig. 2013;93(7):844-54

61. Hollestelle A, Peeters JK, Smid M, Timmermans M, Verhoog LC, Westenend PJ, et al. Loss of E-cadherin is not a necessity for epithelia to mesenchymal transition in human breast cancer. Breast Cancer Res Treat. 2013;138(1):47-57.

62. Siddiqui I, Erreni M, Kamal MA, Porta C, Marchesi F, Pesce S, et al. Differential role of Interleukin-1 and Interleukin-6 in K-Ras-driven pancreatic carcinoma undergoing mesenchymal transition. Oncoimmunology. 2018;7(2):e1388485.

63. Lee H, Herrmann A, Deng JH, Kujawski M, Niu G, Li Z, et al. Persistently activated Stat3 maintains constitutive NF-kappaB activity in tumors. Cancer Cell. 2009;15(4):283-93.

64. Nerstedt A, Johansson A, Andersson CX, Cansby E, Smith U, Mahlapuu M. AMP-activated protein kinase inhibits IL-6-stimulated inflammatory response in human liver cells by suppressing phosphorylation of signal transducer and activator of transcription 3 (STAT3). Diabetologia. 2010;53(11):2406-16.

65. Sun W, Liu DB, Li WW, Zhang LL, Long GX, Wang JF, et al. Interleukin-6 promotes the migration and invasion of nasopharyngeal carcinoma cell lines and upregulates the expression of MMP-2 and MMP-9. Int J Oncol. 2014:44(5):1551-60.

66. Liu Q, Tong D, Liu G, Xu J, Do K, Geary K, et al. Metformin reverses prostate cancer resistance to enzalutamide by targeting TGF-beta1/STAT3 axisregulated EMT. Cell Death Dis. 2017:8(8):e3007.
67. Duan W, Qian W, Zhou C, Cao J, Qin T, Xiao Y, et al. Metformin suppresses the invasive ability of pancreatic cancer cells by blocking autocrine TGFbeta1 signaling. Oncol Rep. 2018.

68. Trinh SX, Nguyen HT, Saimuang K, Prachayasittikul V, Chan On W. Metformin inhibits migration and invasion of cholangiocarcinoma cells. Asian Pac J Cancer Prev. 2017;18(2):473-7.

\section{Publisher's Note}

Springer Nature remains neutral with regard to jurisdictional claims in published maps and institutional affiliations.
Ready to submit your research? Choose BMC and benefit from:

- fast, convenient online submission

- thorough peer review by experienced researchers in your field

- rapid publication on acceptance

- support for research data, including large and complex data types

- gold Open Access which fosters wider collaboration and increased citations

- maximum visibility for your research: over $100 \mathrm{M}$ website views per year

At BMC, research is always in progress.

Learn more biomedcentral.com/submissions 